\title{
The Symbolic meaning of Pinisi Boat Building Ceremony in Ara Village District of Bontobahari Bulukumba Regency: A Semiotic Analysis
}

\author{
Hasniar $^{1}$ and Aser Parera ${ }^{2}$ \\ \{1hasniarsyam95@gmail.com²aserparera21@gmail.com\} \\ 1,2 Hasanuddin University
}

\begin{abstract}
This study aims to determine the symbolic meaning in the Pinisi Boat Making Ceremony in Ara Village, Bulukumba Regency (Study Semiotics). The main issue raised in this study is how the traditional ceremony in making Pinisi boat in the village of Ara, Bulukumba Regency. This research uses descriptive research type. By using a qualitative approach. The instrument used in this study was the researchers themselves with tools in the form of interview guides, cameras and voice recorders. The data analysis technique used is qualitative descriptive data analysis technique. Pinisi is made from pieces of boards with simple equipment based on traditional technological rules, and supported by certain procedures and rituals. Pinisi boat making ceremony is an activity that can be a tourist attraction both locally, nationally and internationally, because the ritual is very specific and has a sale value.
\end{abstract}

Keywords: Semiotic, Cultural Semiotic, Pinisi Boat, Bulukumba, Building Ceremony

\section{Introduction}

The Republic of Indonesia has a variety of cultures, historical backgrounds, natural beauty and people's way of life which are tourist attractions that are spread in various regions of the archipelago, so that many attract researchers. Even though the Indonesian people came from the same ancestor, but because of the territory of Indonesia which is in the form of an archipelago where one island and another island is separated by the sea, this causes differences in life, culture and language between groups of people/tribes. [1]

Traditional boats as a characteristic that belongs to the Indonesian people need to be developed and preserved so that expertise in making pinisi boats remains known and known. With the love of the motherland and national pride, it is necessary to have the means to disseminate knowledge about the role of traditional boats from time to time. The author's data collected so far is data from a traditional cultural and technological repertoire that needs to be known by a broad community of researchers, students, students and the public at large. Expertise in making traditional boats occurs through a long-term process that was pioneered by the Austronesia's nation which is the origin of the Indonesian people. The long journey from the oldest era, the prehistoric era and the influence of Islam to the present has 
provided a vast opportunity for the Indonesian people, which consist of various ethnic groups to develop traditional boats. [2]

Boats from the South Sulawesi area were developed by the Bugis fishing community. The type of boat produced by fishermen from South Sulawei has a very fragrant name even in various parts of the earth. Pinisi boats that have been ordered by various countries such as Germany, Britain, Singapore and others are strong evidence that boats in South Sulawesi are already very well known. Boats in South Sulawesi have very varied shapes with adequate decorative patterns. The highly diverse South Sulawesi boat is probably due to the continued understanding of technology in boat making that has lasted so long, even the symptoms have existed in prehistoric times. The most famous boats from this area are the Palari and Selompong Boat. An interesting type of boat before Pinisi is the Pa'dewakang boat. At this time the traditional boat building expertise South Sulawesi obtained by means inherited from generation to generation.

Boat manufacturing expertise is limited to the people of Ara, Lemo-lemo and Bira. This is very closely related to the biggest lagenda out there. Once upon a time there was a boat known as the Sawerigading boat which was a boat owned by a very powerful person. The boat was stranded on the beach of Ara, at least it was stranded in Lemo-lemo, while the sails and ropes in Bira. Therefore, boat expertise is only owned by residents who live in the area, where there is a part of the damaged Sawerigading boat.

Pinisi can be said to be the symbol and symbol of an extraordinary technical progress and remains based on high artistic values and traditional culture. Because the nature of the Pinisi boat is not only used as a means of transport solely or means of high export commodity value, but also something symbolic. Because of its symbolic nature, in the business of making it and in the processes of launching and using it as needed in traditional ceremonies based on the trust of a power. [3]

\section{Research Method}

This research uses descriptive research type. By using a qualitative approach. The instrument used in this study was the researchers themselves with tools in the form of interview guides, cameras and voice recorders. The data analysis technique used is qualitative descriptive data analysis technique [4].

\section{Results And Discussion}

\subsection{Traditional Pinisi Boat Building Ceremony}

To establish harmony between the rulers of the universe in making boat Pinisi held several ritual ceremonies with certain procedures inherited by their ancestors [5] Say that there are three ritual ceremonies performed by the courtier/panrita lopi in boat making, namely:

\section{1) Cutting down trees (annakbang kalabiseang)}

This basically begged permission for supernatural powers to give up the wood to be cut down. At this ceremony the behavior of the courtier was different than usual which gave a magical impression. 


\section{2) the second ceremony (annattara)}

namely connecting the keel which is a symbol of "meeting" of father and mother as the creation of "fetus" which will then be processed into "baby" in the form of a boat, into the hole (kalabiseang) inserted certain material which is a symbol of the contents of the content of "the mother" which means strength, glory and prosperity. The spell spoken by the retainer is a prayer and spirit that will provide calm and hope for the boat owner. The wood chips (pannatta) are divided in half between the retainer and the boat owner, a symbol of the pledge and agreement between them.

\section{3) Ammosi 'ceremony (ammossi)}

This ceremony is a symbol of 'the birth of the baby boat' after being processed for several months since the formation of the 'boat fetus' at the antr (annattara) ceremony. This ceremony is a sacred ceremony, in which the retainer/Panrita white hooded, smoke incense billowing and mouth whispering something to precipitate a situation solemnly recited mantras and sacred. The ceremony ended with chicken blood smeared on certain parts which meant purity and glory.

\subsection{Symbolic Meaning of Pinisi Boat Building Ceremony Semiotic Review}

\section{1) The felling ceremony paid off (annakbang kalabiseang)}

Kalabiseang or cutting down the keel of the boat (basic beam of the boat) is the basic and main component of a boat, because in this component pieces will be placed in pieces to form a pinisi boat because the wood for the keel material should be selected and quality. But there are some restrictions on choosing paid wood, for example, not using used wood, or wood from fallen trees, drift wood or wood that is defective. If a retainer visits a forest that has a type of wood that will be processed into raw material, the first thing to do is look for a tree that will be used as material (kalabiseang). [6]

If there are already trees that meet the above requirements, according to the BugisMakassar tradition. Usually the day is chosen and is calculated based on the Islamic date, for example the first Wednesday of the current month (Pamula Araba). The selection of days is done when starting important work such as marriage ceremonies, building houses and so on. After a good day was set for the first felling, the mustard provided the equipment/equipment needed for the ceremony.

Basically, this ceremony implies "asking permission" to forest dwellers/trees or the authorities. It is manifested in various forms of governance ways and behavior, as well as the incantations/prayers just before the trees are cut later surrounded the tree while pengamati equipment. Then the equipment is propped up fixed in its position meaning logging can be carried out. If all equipment or axes were propped up earlier when it fell to the ground, it means there is no "permit" from the forest dwellers. In such circumstances, in order to maintain harmony as described above, the courtier must prepare offerings called (kanre sangka) with a newly hatched chick to be offered to forest dwellers.

Usually the first felling starts before noon in the hope that the fortune increases. When the wood has started to fall down, it will be directed to fall into the location of boat making or (help) and also try not to get caught in other trees. This was done with the hope that the implementation of Pinisi boat construction would not experience obstacles or could run smoothly.

After surrounding the tree, then the courtier takes an ax, then takes a position facing the sun. Then regulate your breath and concentrate for a moment that is to hold "occult communication". After the concentration is finished for a moment, then the committee reads the mantra: Pattimbonnako buttayya Katuhoannakobosiya Batelamunnako Lukmanulhakim 
Allah taala anta'bangko Meaning: You are grown by the land you are preserved by rain you planted Lukmanulhakim God is cutting down you.

After completing the chant is continued by chanting the basmalah, then without moving his tongue, say a $\ldots \mathrm{i} \ldots \mathrm{u} \ldots$ and hold his breath, the courtier starts to place his ax. The first number, the ax faces up, which means that it always fared well. After just three times the courtier puts down his ax, then one or two mustard greens help to continue felling until the tree collapses. When the tree has fallen down, the courtier measures the tree trunk by using the footprints which are then cut to make blocks formed in accordance with their standardized uses. As one of the informants said that:

1. It is strongly mounted when felling wood by backing to the sun because the shadows will fall into the trees that are cut. The first tree that collapsed without a hitch is a sign that the cells work anjutnya going smoothly.

2. Kanre sangka' is white, yellow, red and black pulut rice (sangka-complete), which is served together with kalomping, which is specially formed betel leaf filled with lime and a piece of areca nut.

3. There is a belief that offerings and newly hatched chicks are delicate creatures' pleasures.

4. When the courtier concentrates and makes invisible communication with the forest dwellers, the courtier asks that the request is available to make a boat for the "anu". After getting approval (sign), then felling is done.

\section{2) Ceremony to pay off or (annattara)}

Annattara contains the meaning of cutting (in the language of konjo annatta 'in the sense of cutting), which is to cut/flatten the ends connecting the klbiesa (kalabiseang) to be joined by both the front and back joints. This activity is carried out when the boat is going to niptor (nipatonrang), which means it has begun to be carried out, in activities carried out with rituals since hundreds of years ago. In this activity contained in several meanings/symbols that appear from various activities of the Lopi clerks as the main actors of the sacred ceremony. As it is known that the keel of the boat consists of three pieces of blocks, which in the middle are called klbiesa (kalabiseang) which are symbolized as women and the connector, is a symbol of men. In terms of strength, if there is a block of wood that allows (meets the size) the beam can be paid off from one beam [7]

In determining the length kalabiseang (Ihsani), there are at least two things that must be taken into account. First the tonnage (tonnage) of the boat, for pinisi measuring 30-40 tons, the length (kalabiseang) which is 11 footprints, for pinisi measuring 100 tons in length, 17 footprints are settled. Second the fate of the boat. The fixed length specified above can be increased or decreased based on the following steps:

1. Massale- sale (have fun)

2. Sugi Manai (looking for profit)

3. Tallang rilau (drowning in the sea)

4. Mate ribonto (died on land)

The length of a step is based on the width of the surface (the case) compared to the conditions carried out by people who will buy or order a keris, where the steps are sustenance, meetings and death. The size of each step is based on the width of the finger masters. Boat owners usually prefer the end of the step (kalabiseang) to fall on the step (mate ribonto) or die on land. According to their belief that the final step falls on (massala-sale) or (sugi manai), they have not been able to determine how the fate of the boat ends with the crew, whether it sinks at sea or dies on land. If you die on land because the boat is old or weathered then the boat crew will definitely be safe. 
The specified day, the courtier placed the klbiesa (kalabiseang) in the middle of the bantilan which was previously on the base of two pieces of beam. The base extends into the sea and is placed slightly higher than the end with the intention that the boat does not have a downward fate (tattuasa). Before the ceremony begins, the owner/sambalu prepares accessories including two meters of white cloth, a pair of adult chickens, bananas/sweet bananas, sugar, coconut, several kinds of traditional cakes and incense burners.

Shortly before the ceremony procession began, the Panrita took a squatting position at the far right of (kalabiseang) facing east facing the boat owner. The mustard was present at the event and stood behind the courtier, and behind the boat owner stood a number of would-be mustards and boat captains. The entire ceremony is placed around the front end of the kalabiseang including censer. When the expected time has arrived, the ceremony begins which begins with the burning of incense by the courtier. At that time the boat owner put a white cloth on the retainer's head (like a kudung). After the smoke of the incense rose, the courtier smoked the chisel then placed it perpendicular to the boundary line (kalabiseang) and then specifically read the spell as follows: Dalle mambua'ilau Sibuntulangko sicini 'Namarannu pa'mai'nu Mammakkang naha-nahannu Meaning: Rezekidatang in the East You meet each other looking at your happy feelings. Stop your mind.

The entire community is present with food that has been provided such as cakes and bananas. When all the people present enjoyed the food, the courtier took a small portion of each type of cake and wrapped it in banana leaves and then buried it right below (kalabiseang) which was offering to the residents (bantilang).

If there is wood that is possible with the use of kalabiseang or keel that only consists of one beam, it will be much stronger compared to those consisting of three pieces of wooden beams that are joined together. But the previous retainer generally still used wood consisting of three pieces of beam because in addition to the magical value like the previous description, according to some informants that three pieces of keel blocks plus two sotting pieces are symbols of two ruk un-Islam and five prayer times. [8]

1. Wood chips (pannatta') which are divided in half between two thousand and a thousand (sambalu), are symbols/pledges of agreement between them, it can also have another meaning. For the owner of a wooden chip boat can be an "antidote" if the boat is in danger for example by the storm. But on the contrary for a courtier, wood chips can be a "weapon" (potion for use) to harm a boat if a courtier's heart is injured by (sambalu).

2. Material that is inserted into the hole (kalabiseang) or paid off is a symbol of the content of the content of the "mother", each meaningful, namely: a. gold as a symbol of glory b. steel as a symbol of strength c. rice as a symbol of prosperity d. chicken manure is a trusted symbol that can ward off occult knowledge e. cotton rurung (cotton together) as a symbol contains hope that sustenance can be sustained. From the meaning of the symbol above shows hope for the boat to give birth, glory, strength and prosperity and luck.

3. Chicken blood that is put on ice at the connection (kalabiseang) is a symbol of purity and virginity. This can be related to the choice of paid materials, which must be wood that is whole/new, not defective, and used using used wood.

4. There are several versions of the spell that are believed by the lopi clerks to be used in boatmaking ritual activities. Changes in the content of spells are caused by the influence of Islamic beliefs, but the magical situation in each ritual ceremony remains as inherited by the ancestors.

5. Reciting a mantra contains a very essential value, because it can function as a manifestation of an intention that is very important for inner peace. If the spell is identified with prayer then it is very important for inner peace. By praying we foster a sense of optimism 
in humans and keep pessimists and despair away. The reading basmalah mean values of Islam has always upheld setiapa boat building activity (by not leaving the system means a ritual that comes from tradition). While the pronunciation of a ... i ... u.... the lopi clerks believe that the three vowels, the sacred and the third, are believed to be the cosmos.

6. Due to the influence of Islam is so strong, lately the reading of a pledge.... i....u.... often replaced with basmalah readings, but by some members there are also those who combine three sacred letters with basmalah pronunciation.

7. The behavior of the clerks wearing white headscarves with the mouths of our comrades reciting spells and spurting chicken blood smeared on the continuation of the keel, giving the impression of ritual/magical, and sacred.

\section{3) ceremony (ammossi) or administration center}

The supernatural world view in boat making is still believed by the (retainer/panrita lopi) as the first poho $\mathrm{n}$ logging ceremony in the forest (annattara kalabiseang) and (ammossi) Suggestive appreciation of the implementation of the three ceremonies above has transmitted the all sacred situation for some large people who attend the ceremony, because this ritual shows a different behavior than usual. Especially when the retainer with the mouth of the commander to say the incantation while wearing a white hood and puffs of incense and the blood of the spurting chicken had actually precipitated a solemn feeling. [9]

This all-sacred situation seemed to give a clue that those with the courtiers were in a relationship with another world that had enormous powers and could determine their lives in the world. That they must walk in the path of order that has been set by their ancestors, so that the harmonization of the relationship of the smallest symbol and the universe is maintained. [10]

The smallest manifestation of symbols seen on a boat is seen to have qualitative similarities with the model of a village or a stilt house. As where the model of the universe has a center called (boting sky) or in the middle of the sky, the boat as the smallest symbol also has a center called (possi).

Making posi (possi) as mentioned above is done before the boat is launched and usually carried out at night. Similar to annattara, the implementation is carried out with a ritual ceremony which is a symbol of the "baby birth" of the boat. The ceremony begins with the apsili ceremony (appassili) and ends with the (appakanre). The implementation is carried out on certain days which are deliberately chosen based on the habits of the Bugis Makassar community. Appassili is a ritual event performed on the night before (ammossi), and aims to refuse reinforcements. Today the appassili ceremony is carried out together with the amosiation ceremony (ammossi), which has been influenced by Islamic elements including the reading of Barazanji and so on. Before the ceremony is carried out, first of all the equipment must be prepared, including a kettle taken from a certain spring. [11]

For completeness also prepared a bunch of foliage which consists of leaves (sidingin) or, (sinrol), (taha tinappasa), (taha siri), (panno-panno), which are bound together (pimping). Bonds of leaves and water are believed to contain the following meanings. [12]:

a. Water taken from a particular spring, is believed to have good fortune never

b. Leaf (sidingin), meaning the owner and crew of the boat is always in a calm condition/light

c. Sinrolo, a type of vines whose growth is very fast so it is expected that the growth of luck will still increase.

d. Taha tinappasa, meaning to reject the disturbance of spirits/evil spirits so as to avoid being out of danger. 
e. Taha siri or shame/self-esteem, it is expected that the owner of the boat has a sense of selfworth and shame if he does not succeed

f. Panno-panno or full, is a kind of leaf which is expected to mean sustenance always full/pimping which is a type of sugar cane (elephant grass stems) which when dry is very light/can float means it always has good luck/fate is always on the surface.

Before the reading of barzanji by certain groups, a group meal was first attended, attended by traditional leaders, Lemo-lemo Ara and Bira village leaders, religious leaders and relatives. Many people who attended the evening of the completeness of the event, also prepared traditional cakes, each containing meaning/symbol, among others (gogoso), (kolapis) or layer cake, (onde-onde), (songkolo) or steamed, (kaddo masingkulu) and so on. The way for the ceremony according to the informant is that after finishing eating together and the equipment/materials for the ceremony are ready on the boat, the implementation of the ceremony (members of the barzanji) read the barzanji to completion. During the reading of the barzanji, all those present continued to follow with reverence. Barzanji readers take positions on the deck of the boat and face each other. After completing the reading of the barzanji, a (sara'teacher) is specially groomed, read (songkobala) and then faces the pan filled with water (taken from a spring) and a bunch of leaves to recite the spell very solemnly and solemnly. Water taken from a spring is then chatted while stirring using a bunch of leaves that had been prepared beforehand. Water that has been spelled is called water (songkabala). Then water is sprinkled around the boat by way of wagging by using bonding foliage. After the ceremony is over, the guests are re-entertained with traditional cakes including ambon bananas that have been prepared. Overall traditional cakes are believed to contain meanings/symbols, including: [13]

1. Gogoso or gogos in the konjo language commonly referred to as a'gogosoberm Meaning collecting fortune/wealth

2. Kolapis or layer cake, meaning to get a multi-layered fortune

3. Onde-onde, means that the impression is sweet and savory

4. Kaddo massingkulu, meaning to reject reinforcements

5. Songkolo or steam, meaning union

6.Unti labbu or long banana/ambon banana, meaning that the owner's life is long-lived.

\section{Conclusion}

Based on the belief of the Lopi Panrita, a boat is a form that has an existence like humans. A boat is a life figure that is the smallest symbol of the universe. Traditional boat building is a livelihood that is able to absorb a lot of labor. In Bontobahari sub-district, Bulukumba Regency, there are around 1,300 adult men who depend on their families to work as boatmen. With the income from boatmen, they can live in a decent way with villagers and their families. Traditional boat building is a livelihood that is able to absorb a lot of labor. In Bontobahari sub-district, Bulukumba Regency, there are around 1,300 adult men who depend on their families to work as boatmen. By producing the boatman, they can live well as villagers with family. There are two things that a craftsman wants to achieve in making a boat, the first material is compensation for the services of workers and skills, the second is the desire to acquire and master technical knowledge and skills. A courtier/clerk's lopi also has a double war that is as an employer of his mustard, and also as a teacher who must delegate his skills and knowledge to his husband. 


\section{References}

[1] H. Sukendar, Pustaka Wisata Budaya Perahu Tradisional Nusantara. Jakarta: Proyek, 1999.

[2] Dunia pelajar, "Pengertian adat istiadat," 2014. .

[3] Abbas, Pinisi perahu khas Sulawesi Selatan: Kebudayaan Dinas Kebudayaan. 2001.

[4] K. Saddhono, "Language of coastal communities in the northern coast of central java: sociolinguistic studies in cultural integration maritime-agrarian perspective," Adv. Sci. Lett., vol. 23, no. 10, pp. 10054-10056, 2017.

[5] mattulada, Kebudayaan Bugis Makassar: Manusia dan Kebudayaan di Indonesia. 1998.

[6] N. Dewi, "Upacara pembuatan Perahu Pinisi di Kecamatan Bonto Bahari Kabupaten Bulukumba," 2016.

[7] D. dan U. B. Pradjoko, Alas Pelabuhan-Pelabuhan Bersejarah di Indonesia. Direktorat Jendral Kebudayaan, 2013.

[8] Kurniasari, "Dimensi Religi dalam Pembuatan Puisi," J. Sos. Ekon. Kelaut. dan Perikan., vol. 8, 2015, doi: 10.15578/jsekp.v8i1.1197.

[9] Sambodo, Profil Budaya dan bahasa Kabupaten Bulukumba. Jakarta: Pusat data dan Sttistik pendidikan dan kebudayaan, 2019.

[10] I. Jaya, "Analisis pola hubungan kerja dan sistem bagi hasil pada pembuatan kapan pinisi di kabupaten Bulukumba," 2018.

[11] Asnira, "Makna Perahu pinisi Bagi Punggawa di Kelurahan Tanah Beru Kabupaten Bulukumba," 2018.

[12] K. Jamil, "perahu Pinisi Sebagai Lambang Kabupaten Bulukumba,” Uin Alauddin, 2016.

[13] D. I. Bulukumba, T. Fajrah, and I. Mj, "Artikel ini merupakan tugas akhir mata kuliah WSBM Kelas Kesmas C, FKM, Universitas Hasanuddin 2018." 